\title{
The Inherent Tensions within Sustainable Supply Chains: A Case Study from \\ Bangladesh
}

Mahmud Akhter Shareef

North South University, Bangladesh

Email: mahmud_akh@yahoo.com

Yogesh K. Dwivedi

Emerging Markets Research Centre (EMaRC)

School of Management, Swansea University Bay Campus

Fabian Way, Swansea, Wales, UK

Email: ykdwivedi@gmail.com

\author{
Vinod Kumar \\ Sprott School of Business - Carleton University, Canada \\ Email: vinod.kumar@carleton.ca
}

\section{Rasheek Mahmud}

Human, Environment \& Resource Development for Society (HERDS)

Email: rasheekmah@gmail.com

\author{
D. Laurie Hughes \\ Emerging Markets Research Centre (EMaRC) \\ School of Management, Swansea University Bay Campus \\ Fabian Way, Swansea, Wales, UK \\ Email: D.L.Hughes@Swansea.ac.uk \\ Nripendra P. Rana \\ School of Management, University of Bradford, UK \\ Email: nrananp@gmail.com \\ Hatice Kizgin \\ Emerging Markets Research Centre (EMaRC) \\ School of Management, Swansea University Bay Campus \\ Fabian Way, Swansea, Wales, UK \\ Email: Hatice.kizgin@swansea.ac.uk
}

\begin{abstract}
The complexities surrounding the supply chain logistics for perishable commodities within Bangladesh are extensive. Poor infrastructure, fragmented transportation and corruption compound the operational complexities within this emerging market. This case study analyses many of the day-to-day operational challenges and tensions inherent within Micro-Small-Medium Enterprises (MSMEs) forming the backbone of the Bangladesh socio-economic structure. The drive for transition toward greater levels of sustainability and corporate responsibility is
\end{abstract}


problematic, affecting many levels within an extended and fragmented supply chain. The selected case study highlights the "lived in" geographical, environmental, economic and cultural factors that impact the ability of emerging market enterprises to remain profitable within emergency scenarios whilst transitioning toward a more sustainable model. This study, whilst detailing many of the tensions and critical issues facing MSMEs, highlights the benefits of direct Government intervention, criticality of a leaner and more efficient supply chain and reassessment of financial incentives to drive the transition to a more efficient and sustainable economy.

Keywords: Hilsa, Micro-Small-Medium Enterprises, Supply Chain Management, Emerging markets, Government supervisory role, Procurement, Effective distribution network.

\section{Introduction}

The selected case explores the operational and logistics complexities surrounding the distribution of hilsa fish within Bangladeshi internal markets. The hilsa fish is a herring like species that is a popular food product amongst the people of South Asia and is the national fish of Bangladesh. Approximately 496,417 tonnes of hilsa fish are produced annually, bringing a substantial amount of foreign currency to the country through exports to neighbouring countries (BOLME, 2011; Hoque et al., 2017; Salini et al., 2004). Hilsa contributes around 12\% of the overall fish production, equivalent to $1 \%$ of Bangladesh's GDP. Over 2 million Bangladesh people are involved in the hilsa fish value chain from fishing, transportation, wholesale, retail, fishing supplies, boat manufacturing, ice production and distribution, packaging, processing and exporting (Ali et al., 2017).

The potential for effective sustainability of perishable food items such as fish depends on the scope and capacity of commercialisation in the market economy (Balcik et al., 2010; Davis et al., 2013; Dreyer et al., 2016). Innovative ideas that directly impact the supply chain can emerge, but if the Bangladeshi fishermen fail to successfully commercialise their products and support sustainable supply chain efficiencies, meaningful change is unlikely to be realised in this valuable sector. The barriers to an improved and sustainable supply chain leading to greater levels of operational effectiveness are numerous. Issues such as: stock assessment, breeding biology, population structure, development and migration patterns, biological productivity and climate change, all complicate meaningful transition. Furthermore, the supply chain management of hilsa also suffers from the requirement to precipitously manage excessive supply of hilsa in a scenario where this extensively surpasses all local demand (Ahmed, 2007; Haque, 2011). Balancing this supplydemand curve and logistical complexity is problematic in this emerging market context (Ahmed, 2007; Ardjosoediro and Goetz, 2007; Noor, 2012).

The hilsa supply chain exhibits a number of specific issues that necessitate further analysis and study. Generally, the supply and processing of hilsa fish is inadequate and not aligned with demand. Crucial elements of the supply chain are unable to effectively store and transport product to all stakeholders. On many occasions fishermen can catch huge amounts of hilsa within many Bangladesh coastal regions (Cox's Bazar, Patuakhali, Barguna, Barisal, Bhola), however, due to the poor logistics and market infrastructure, the supply chain breaks down and product is either dumped or sold onto middlemen at drastically reduced prices. Most fish become inedible within twelve hours at tropical temperatures and spoilage begins as soon as the fish dies unless frozen or 
cold stored (Ahmed et al., 2008; Alam et al., 2012; Rahman et al., 2012). This lack of an adaptive and flexible supply chain for the timely distribution and storage of excessive hilsa, is a significant problem and resulting economic loss to the people of Bangladesh.

Recognising the key stakeholder role occupied by the hilsa fishermen is key, as this population group needs to feel they are benefiting from any move toward greater levels of supply chain efficiencies and sustainability. The government of Bangladesh has embarked on numerous initiatives to strengthen hilsa operations and management by focusing on the sustainability and efficient farming of fish stocks (Hussain and Hoq, 2010). However, scant attention has been directed both from an academic and institutional perspective, on the supply chain complexities and challenges particularly during periods of excessive supply and time pressured sustainable logistics. This gap in the research exposes the necessity for a deeper analysis in a case study context of the potential for a more effective and sustainable supply chain, but also the effective emergency logistics management within a time critical context.

Developing sustainable supply chains for fish product is extremely important for many countries throughout the world (Garcia-Garcia et al., 2015). An effective supply chain of perishable food products can help in supporting the actual producers (farmers and fishermen) as well as the end customer (Irani et al., 2018). The processes and controls governing these effective supply chains must be cognisant of food security. Issues relating to sustaining levels of production, as well as more social and ecological factors, can potentially impact global food security (Lang and Barling 2012; Vlajic et al., 2013; Wu et al., 2011; Zheng et al., 2017). Studies have highlighted a number of these factors supporting the criticality of ensuring integrating food security processes and controls within the extended supply chain for perishable products (Irani et al., 2018; Kummu et al., 2012; Midgley, 2013).

The distribution of hilsa fish within Bangladesh can be challenging but also conflicting due to the diverse interests of the multitude of stakeholders and inefficiencies of the existing and extended supply chain. The development of sustainability in this context raises many issues and challenges for academic research. Studies have analysed many aspects of supply chains and logistics within emerging markets, highlighting the inherent social and cultural complexities that act as barriers to effective change (Ali et al., 2017; Ardjosoediro and Goetz, 2007; Balcik et al., 2010). However, although existing studies have analysed a number of the sustainability issues within the fisheries industry in Bangladesh and associated markets (Halder, 2002; Hoque et al., 2017), researchers have yet to analyse the hilsa specific supply chain and distribution complexities in alignment with the existing relevant emerging markets based literature. This study aims to deliver academic contribution by offering a timely perspective to many of the lived in issues within this emerging market supply chain, using a case study approach to highlight the complexities and multidimensional tensions between the different stakeholder interests. This research offers new insight to the fragmented nature of the existing supply chain aligned with a number of interrelated critical problem factors. The paper develops a rigorous analysis of many of these critical factors offering valuable and timely contribution to the sustainability focussed literature and presents a number of key recommendations for government and dependent stakeholders. 
The remainder of the paper is structured as follows: section 2) details the literature review, section 3 ) discusses the research methods used, section 4) the data analysis and results, the discussion section is presented in section 5), the paper is concluded within section 6).

\section{Literature Review}

A number of previous studies have analysed the sustainable supply chain management of food products, concluding that the nature of procurement and distribution, particularly logistics management of perishable items, exhibits inherent complexities that are absent from many component based supply chain networks (Ali et al., 2017; Balcik et al., 2010; Davis et al., 2013; Dreyer et al., 2016; Dubey et al., 2017a; Kummu et al., 2012). The efficient and timely transportation required for perishable products, highlights the vulnerability within the emerging market context and criticality of effective logistics (Balcik et al., 2010; Davis et al., 2013; Dreyer et al., 2016). Researchers have highlighted the vulnerability of many aspects of the food-based supply chain due to transportation and logistics inefficiencies and poor management (Dubey et al., 2018; Gopal \& Thakkar, 2016b; Marshall et al., 2015). Considering the urgency of distribution of agricultural products and other food items, any kind of uncertainty in supply and availability of transportation system can jeopardize the entire supply network (Gopal \& Thakkar, 2016a; Grimm, et al., 2014; Kiil et al., 2018; Moazzam et al., 2018; Ransikarbum \& Mason, 2016a). Research relating to many aspects of food security is an active research topic where the development of sustainable supply chains has a compounding impact on the globalization of food items. The supply chain of perishable food items, where stakeholders exhibit multifaceted and often conflicting interests, can detrimentally affect food security (Midgley, 2013; Shibin et al. 2018;). Studies have posited the significant benefits to food security via the effective management of the supply chain (Irani et al., 2018; Midgley, 2013; Stevenson \& Spring, 2009). These factors are directly applicable to the many issues inherent within the hilsa supply chain.

Adequacy in storage and packaging is another key factor for perishable food products especially in labour intensive, non-mechanised markets (Ali et al., 2017; Balcik et al., 2010; Irani et al., 2018; Kummu et al., 2012). The availability of adequate human resource for storage, packaging, and transportation, is often more important than the typical performance of different stakeholders involved in supply chain network. Studies have highlighted many of these factors highlighting logistics inefficiencies, lack of coordination between elements of the supply chain and inadequate storage and transportation equipment (Dubey et al., 2014; Hasin et al., 2000; Hasegan et al., 2018; Heaslip et al., 2012; Hung \& Ryu, 2008; Ou et al., 2010; Prater et al., 2001).

In scenarios of extreme over-supply, the standard processes used to manage demand can be wholly inadequate. This leads to price and profit manipulation by influential stakeholders, emphasising the inability of the existing market mechanism to effectively coordinate supply and demand (Fahimnia et al., 2015; Jabbour et al. 2017; Zhu et al., 2012). In this context, a multitude of supply chain complexities are in play that exacerbate the potential for successful outcomes (de Camargo Fiorini et al. 2017; Dubey et al. 2017a,b; Kshetri, 2018; Queiroz, \& Wamba, 2019; Shiau et al. 2015; Zhu et al., 2012). Studies have highlighted a number of factors associated with the emergency distribution and logistics management through established supply chain networks (Irani et al. 2010; Seles et al. 2016; Wu \& Chiu, 2018). Complexities relating to: non-cooperation amongst stakeholders with vested interests, disrupted supply chain communication, poor logistics 
and inefficient distribution network, corruption, poor communication and lack of coordination amongst stakeholders (Diallo et al., 2017; Hussain \& Uddin, 1995; Shareef et al., 2017; Su et al., 2008; Surana et al., 2005). Many of these factors directly relate to the numerous problems inherent within the hilsa supply chain. Previous studies have also discussed aspects of the hisa fishing industry (Alam, 2011; Alam et al., 2010; Halder, 2002; Rabby et al., 2015; Sakib, 2012), however, the existing literature has not exposed many of the complexities and tensions relating to the many component of the supply chain that are addressed within this study. Discussion presented above led to identify several research gaps from the existing literature, which are listed in Table 1.

Table 1: Research Direction and Literature Gap

\begin{tabular}{|c|c|c|}
\hline Existing Studies & Main Findings & Research Gaps \\
\hline $\begin{array}{l}\text { Balcik et al., 2010; Davis et al., 2013; } \\
\text { Dreyer et al., 2016; Dubey et al., } \\
\text { 2017a; Kummu et al., } 2012\end{array}$ & $\begin{array}{l}\text { Complexities in logistics management and } \\
\text { effective design of supply chain }\end{array}$ & \multirow{5}{*}{$\begin{array}{l}\text { - Conflicting nature } \\
\text { among the stakeholders } \\
\text { of the same supply } \\
\text { networks } \\
\text { - Involvement of } \\
\text { government } \\
\text { - Integrated coordination } \\
\text { system imposed by } \\
\text { government }\end{array}$} \\
\hline $\begin{array}{l}\text { Dubey et al., 2014; Hasegan et al., } \\
\text { 2018; Heaslip et al., 2012; Hung \& } \\
\text { Ryu, 2008; }\end{array}$ & $\begin{array}{l}\text { Lack of coordination and storage problems } \\
\text { in supply chain }\end{array}$ & \\
\hline $\begin{array}{l}\text { Irani et al., 2010; Seles et al., 2016; Wu } \\
\& \text { Chiu, } 2018\end{array}$ & $\begin{array}{l}\text { Problems of different driving forces of } \\
\text { supply networks }\end{array}$ & \\
\hline $\begin{array}{l}\text { Diallo et al., 2017; Hussain \& Uddin, } \\
\text { 1995; Shareef et al., 2017; Su et al., } \\
\text { 2008; Surana et al., } 2005\end{array}$ & $\begin{array}{l}\text { Poor communication and non-cooperative } \\
\text { elements in supply chain }\end{array}$ & \\
\hline $\begin{array}{l}\text { Alam, 2011; Alam et al., 2010; Halder, } \\
\text { 2002; Rabby et al., 2015; Sakib, } 2012\end{array}$ & $\begin{array}{l}\text { Typical storage and distribution problems } \\
\text { in perishable food items }\end{array}$ & \\
\hline
\end{tabular}

\section{Research Methods}

This study collects data from key Bangladeshi supply chain stakeholders via the semi-structured interview method. The interviews were conducted "in the field" at a number of locations designed to gain a sufficient cross section of views. The interviews focussed on many of the issues of sustainability within the supply chain of fish products. The researchers interviewed stakeholders representing varied stakeholder interests at different phases of supply chain of hilsa fish. To confirm reliability and validity of the information collected from the interviews, triangulation method was applied (Moon, 2019). From the triangulation method this study employed three procedures: method triangulation, investigator triangulation and data source triangulation as per the recommendation of Moon (2019). This study has deployed several methods to collect appropriate information including: direct questionnaire, observation and discussion. This process ensured that the validity and reliability of the collected information representing the actual scenario was confirmed.

Application of triangulation method in data collection ensured the non-biasness of collected information. All the possible stakeholders were identified and considered for semi-structured interviews to identify the problems, conflicts, and non-cooperation in existing supply chain. Thus, validity was confirmed for this kind of case study (Ketokivi and Choi, 2014; Fernández Campos et al. 2019). A focus group was also formed to review the questionnaire of the interviews. The sequence depicted in Figure 1 was followed to ensure conducting this case study in appropriate manner. 


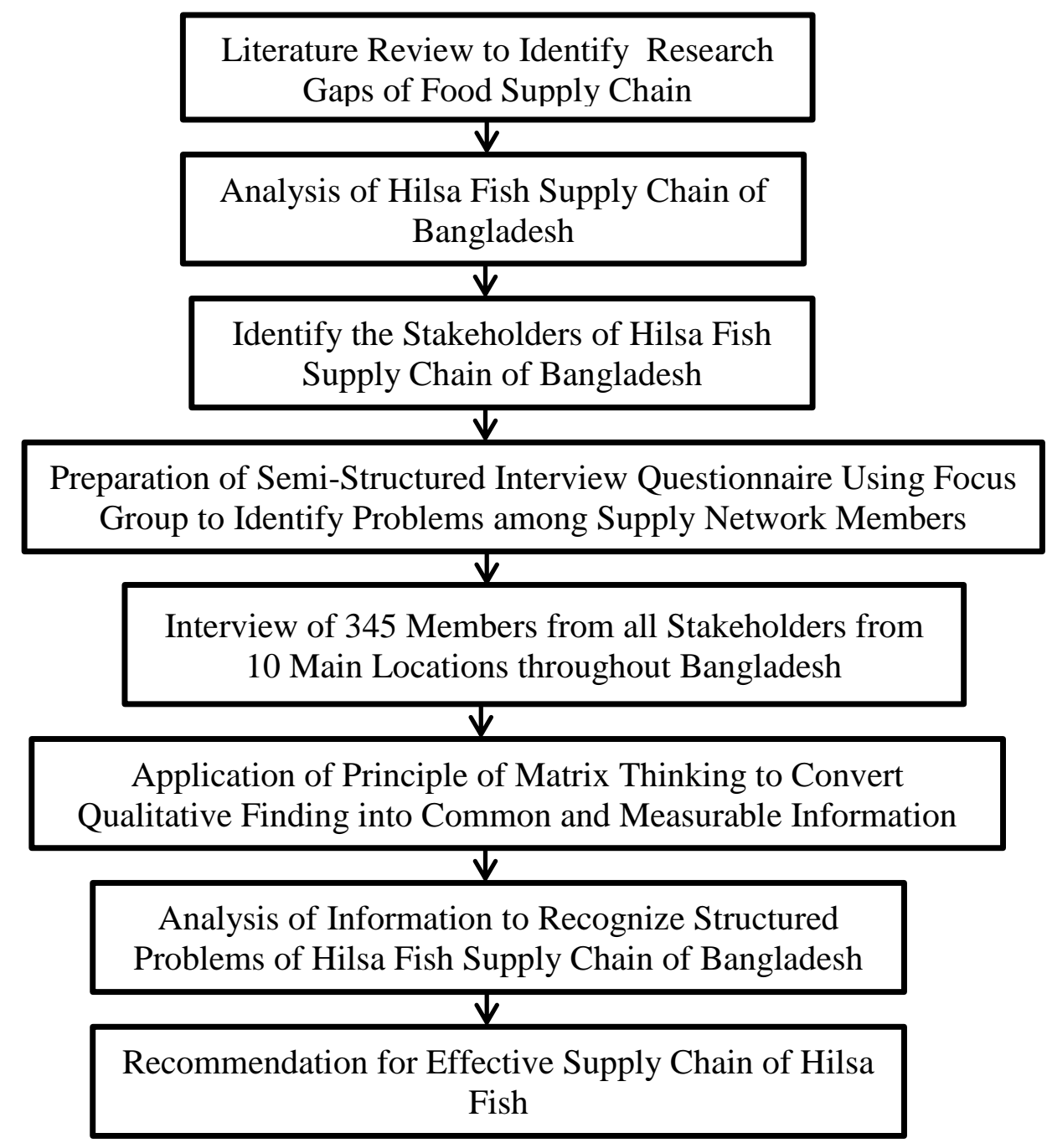

Figure 1: Research Steps and Activities

Following the recommendations of previous studies on the merits of a case study approach (Eisenhardt, 1989; Meredith, 1998; Pagell and Wu, 2009; Barratt et al. 2011), this method was selected as the most appropriate to generate our research propositions and develop our findings. To ensure this study was able to effectively analyse the critical components of the supply chain, stakeholders were selected from a number of different phases of the hilsa lifecycle. The following stakeholder types were analysed for participants:

- Hilsa procurement

- Local storage

- Wholesale

- Local and intercity transportation and logistics management

- Countrywide storage

- Countrywide distribution

- Retailing

- Ancillary resource collection 
- Overall government monitoring

Based on the component elements of the supply chain types listed above, a number of stakeholder groups were selected: 1) Fishermen (Funded); 2) Fishermen (Independent); 3) Original investors (Mohajan) who pledge advances to fishermen to get the complete ownership; 4) Auctioneer/Wholesaler/Commission agent (Source); 5) Unauthorized Wholesaler (Source); 6) Store Owner (District level Market) (Aarotder/Mokum); 7) Auctioneer/Wholesaler (District level Market); 8) Retailer; 9) Management of transportation; 10) Management of cold storage; 11) Ice manufacturer and supplier; 12) Government fisheries department; 13) End consumers.

In order to understand and reveal the primary antecedents that have causal effect in developing a sustainable hilsa supply chain strategy, this study has conducted a number of semi-structured interviews amongst major influential stakeholders. The questionnaire was developed and reviewed via a focus group to validate content and meaning relating to potential outcomes. Respondents were requested to provide their detail perceptions, complaints, and recommendations reflecting own expectation and experience based on the semi structured questionnaire. They had the options to add, revise, and extend their views from other areas related to the supply chain of hilsa fish. The primary ten questions which were used as the foundation of these interviews are listed in Appendix A. Under this context, the study has explored all the major stakeholders' perceptions, i.e., those people who are actively related or needed to provide ancillary support for optimization of fish distribution from a supply chain management perspective as well as marketing and final retail perspectives. The study selected ten locations (market/distribution centre, districts ways) to conduct the interviews through consultation with the relevant authorities: Chandpur, Chattagram, Cox's Bazar, Patuakhali, Borguna, Barisal, Dhaka, Khulna, Lakshmipur, and Bhola districts. From each location, a minimum one to a maximum of five people were interviewed from each stakeholder group. The respondents were interviewed between October, 2018 to February, 2019. A total of 345 members from different stakeholder groups were interviewed.

\section{Analysis of Results}

The respondents addressed and introduced several issues related to the malfunctioning of market management with multidimensional parameters and reasoning. Their expectations, experiences, perceptions, and recommendations were analysed through the commonality in the keywords and concepts mentioned. To present the key data obtained from interviews, the ideas were divided, categorized, and rearranged according to the principles of matrix thinking (Patton, 1981). In this way, long comments and information were broken down into small significant variables to figure out recognized common attributes. Finally in alignment with supply chain parameters, this study categorized the answers into different groups identifying the constructs reflecting the generic and Bangladesh specific problems. Qualitative analysis was conducted to synchronize the information to represent non-biasness of data. As the data was collected from several sources following using a number of methods (direct questioning, informal discussion, and observation) we posit that the collected data and its analysis can represent an accurate and true reflection of the multitude of issues inherent within the Bangladesh hilsa supply chain. The revealed attributes from the analysis can provide deep insight to develop a theoretical framework for hilsa fish supply chain from procurement to final consumption.

A summary of the collected data is presented in Table 2. 
Table 2: Summary of Data Source

\begin{tabular}{|c|c|c|}
\hline Stakeholder & \#Interviewed & Role \\
\hline Fishermen (Funded) & 30 & $\begin{array}{l}\text { Catches fish from Bangladesh rivers and coastal areas. All resources } \\
\text { including boat, net, food are secured from local investors/store owner } \\
\text { (Aarotder). They are the origin of this hilsa supply network. They are } \\
\text { mostly poor with low standards of education and predominantly male. }\end{array}$ \\
\hline $\begin{array}{l}\text { Fishermen } \\
\text { (Independent) }\end{array}$ & 10 & $\begin{array}{l}\text { Catches fish from rivers and coastal areas. However, the fishing is } \\
\text { undertaken independently without any funding from investors. Thus, } \\
\text { they can sell their catch to any party. They operate at a small level. They } \\
\text { are mostly self-dependent and more knowledgeable than funded } \\
\text { fishermen. }\end{array}$ \\
\hline $\begin{array}{l}\text { Original Investor/Store } \\
\text { Owner (Mohajans) }\end{array}$ & 50 & $\begin{array}{l}\text { Invests money in the fishing infrastructure prior to the hilsa season. } \\
\text { They have rights and ownership of the full catch when brought to the } \\
\text { primary market. In local language, they are called as Mohajan } \\
\text { (Investor) and generally manage multiple interests within the supply } \\
\text { chain. Some of the Mohajan are educated and are mostly male. }\end{array}$ \\
\hline $\begin{array}{l}\text { Auctioneer/Wholesaler/ } \\
\text { Commission agent } \\
\text { (Source) }\end{array}$ & 50 & $\begin{array}{l}\text { Buys fish from the primary market by auction. They function as a } \\
\text { wholesaler or Commission agent. They manage the business of multiple } \\
\text { fish products. Generally they exhibit some level of education and are } \\
\text { mostly male. }\end{array}$ \\
\hline $\begin{array}{l}\text { Unauthorized } \\
\text { Wholesaler (Source) }\end{array}$ & 10 & $\begin{array}{l}\text { The unauthorised wholesaler does not buy hilsa fish from any } \\
\text { recognized market; rather they rely more on illegal selling of fish by } \\
\text { some fishermen who have received funding from investors or retail } \\
\text { fishermen who are independent. Some of them are educated and are } \\
\text { predominantly male. }\end{array}$ \\
\hline $\begin{array}{l}\text { Store Owner (District } \\
\text { level Market) } \\
\text { (Aarotder/Mokum) }\end{array}$ & 50 & $\begin{array}{l}\text { Wholesalers distribute fish to the district level store owner (Aarotder), } \\
\text { also termed as Mokum. They are the central point of the forward linkage } \\
\text { in the district level. They manage the business of multiple fish products. } \\
\text { Some of them are educated and generally male. }\end{array}$ \\
\hline $\begin{array}{l}\text { Auctioneer/Wholesaler } \\
\text { (Market) }\end{array}$ & 20 & $\begin{array}{l}\text { Market auctioneers/wholesalers are the true middlemen at the district } \\
\text { level. They buy fish to sell to district level retailers. They manage the } \\
\text { business of multiple fish products but generally specialise in hilsa fish. } \\
\text { Generally, they are not educated and male. }\end{array}$ \\
\hline Retailer & 30 & $\begin{array}{l}\text { Acts as the district level retailers who buy fish from a central wholesaler } \\
\text { and sell the hilsa to different local markets. Sometimes, they manage } \\
\text { the business of multiple fish products however, mostly engaged in hilsa } \\
\text { fish. Generally, they are not educated and are male. }\end{array}$ \\
\hline $\begin{array}{l}\text { Management of } \\
\text { transportation }\end{array}$ & 20 & $\begin{array}{l}\text { Typically inter-district truck owners who transport fish from the origin } \\
\text { (source) market recruited by either original investors/store owners } \\
\text { (Aarotder) to collect fish from fishermen to their stores or } \\
\text { auctioneer/wholesaler (Source) to distribute fish to store owner (district } \\
\text { level market) (Aarotder and Mokum). They are mostly engaged in } \\
\text { typical commission agent type business. They seem to be partly } \\
\text { educated and male. }\end{array}$ \\
\hline $\begin{array}{l}\text { Management of Cold } \\
\text { storage }\end{array}$ & 10 & $\begin{array}{l}\text { Manages the cold storage facilities within the supply chain. Typically } \\
\text { they are located in the zone of source market (collection). Generally, } \\
\text { they are semi-urban business people, educated, and moderately } \\
\text { affluent. They are mostly male, however, female cold storage owners } \\
\text { are also involved. }\end{array}$ \\
\hline
\end{tabular}




\begin{tabular}{|l|l|l|}
\hline $\begin{array}{l}\text { Ice manufacturer and } \\
\text { supplier }\end{array}$ & 10 & $\begin{array}{l}\text { Ice manufacturers and suppliers produce ice products for transportation } \\
\text { to a number of locations. However it is more important in the backward } \\
\text { linkage. Generally, they are urban, semi-urban, and rural business } \\
\text { people. Generally, they are male and little educated. }\end{array}$ \\
\hline $\begin{array}{l}\text { Government fisheries } \\
\text { department }\end{array}$ & 5 & $\begin{array}{l}\text { Government authority who monitor and regulate the policies of hilsa } \\
\text { fish procurement. They are mostly male dominated; however female } \\
\text { government officers in this sector are also available. They are highly } \\
\text { educated and government policy makers. }\end{array}$ \\
\hline End consumers & 50 & $\begin{array}{l}\text { End buyers who buy fish from different markets, typically from } \\
\text { retailers. End consumers of hilsa fish are mostly educated and middle } \\
\text { class to rich people. Distribution of male and female as the end } \\
\text { customer is almost even. }\end{array}$ \\
\hline
\end{tabular}

Stakeholders can be broadly grouped into three categories: a) backward linkage, b) forward linkage and c) supporting sources.

\section{Backward Linkage:}

This category in the supply chain of hilsa fish represents those stakeholders who fundamentally are engaged in fish procurement stage. These are:

\section{Fishermen (Funded)}

This group is the core stakeholder at the commencement of the supply chain. Funded fishermen are equipped with boat drivers, assistants, and up to 15 other people that perform various functions relating to catching fish. Fish are caught within Bangladesh rivers and coastal areas. Original investors/store owners (Aarotder/Mohajan) invest money and bear all the costs of the fishermen including catching fish and supporting the daily livelihood of fishermen. In exchange for this, fishermen do not have any freedom to sell fish elsewhere without the permission of investors. When the fishermen catch fish they transport the haul to the local procurement market of the Aarotder/Mohajan via truck or manual-vehicles. After deduction of all investor related charges including an ownership fee of typically $6-8 \%$, the fishermen receive about $50 \%$ of the revenue from the catch. The payment of this is typically done at the end of the season. Infrequently, fishermen illegally sell a proportion of the catch to unauthorized wholesalers.

\section{Fishermen (Independent)}

A small number of fishermen do not form part of the funded network and are thus able to sell their fish to the highest bidder. Generally these fishermen do not transport and sell at the local markets but sell to free wholesalers beside the riverbanks. Prices are not guaranteed and transactions can take place outside of the Aarotder/Mohajan network control.

\section{Original Investors/Store Owner (Mohajan)}

These are the key stakeholders within the supply chain representing the primary owner in the backward linkage of hilsa fishing. They are also known as "Aarotder" or Mohajan, meaning the owner of the central procurement market where all appointed fishermen transport the hilsa. The Mohajan arrange auctions to sell the catch, these are conducted at any time in the morning or evening. Investors retain $6-8 \%$ of the hammer price as commission. The fishermen net approximately $50 \%$ of the auction price after deduction of expenses and the initial investment. This stakeholder is extremely influential and are typically powerful local businessmen. 
Auctioneer/Wholesaler/Commission agent (Source)

This group is the last stakeholder of backward linkage and key player in managing, manipulating, and controlling the distribution. Through auction, the highest bidder buys the entire catch of fish. Then they categorize the fish according to size, collect ice pallets, pack each of the fish, organize transportation and send to the nominated market district. The wholesaler will transport the hilsa catch to destination markets based on highest offer prices.

\section{Unauthorized Wholesaler (Source)}

Unauthorized wholesalers are sometimes involved in the illegal trading of fish from fishermen who are funded by investors. These wholesalers also purchase fish from independent fishermen. The catch is sold to store owners (District level Market) (Aarotder). These unauthorized wholesalers gain the advantage of a smaller supply chain with less middlemen and therefore, greater cost advantages. However, storage and preservation is less organized and product quality suffers as a result.

\section{Forward Linkage:}

This is the distribution side of the hilsa supply chain and represents the market infrastructure.

\section{Store Owner (District level Market) (Aarotder/Mokum)}

At the district level, middlemen - Aarotder also known as Mokum receive the hilsa from the auctioneers. The amount and size of fish purchased by these stakeholders depends on market demand. Generally a markup of $3 \%$ is received based on wholesale prices.

\section{Auctioneer/Wholesaler (Market)}

These local wholesalers purchase hilsa from the Aarotder and sell to retailers. This section of the supply chain is stable but prices can fluctuate based on supply.

\section{Retailer}

Retailers tend to be sellers within different markets inside many Bangladesh towns and cities. This section of the supply chain is volatile as prices fluctuate. Quality issues can impact the product at this stage as the preservation process is not formalized.

\section{Supporting Sources}

To facilitate the procurement, preservation and distribution, logistics management and other ancillary services are mandatory for managing supply chain of hilsa fish. These services are termed here as supporting services. The significant supporting services may include:

\section{Management of Transportation}

This is one of the vital components of logistics management (Ransikarbum \& Mason, 2016b) and is critical to the supply chain due to the perishability of the product. At three phases, this supply chain requires transportation and logistics management. During the procurement phase when fishermen carry fish from river or sea banks to the market place of the investors, they hire trucks, 
vans, or some human hauler vehicles. After procurement from the investors' stores, the auctioneers distribute the fish to the desired market within another district. The transportation may be for longer periods as the principal auctioneers distribute the fish as per demand via trucks. District level retailers carry fish from district wholesale market to their own markets by trucks, vans, or human hauler vehicles. Owners of transportation tend to leverage their role in fish distribution, particularly in the emergency period when supply of fish is excessive and demand for transportation is the highest.

\section{Management of Cold Storage}

The availability and management of cold storage is a critical element of the supply chain a for any perishable food item in Bangladesh. Throughout the year demand of this service tends to outstrip supply. As a result, there are insufficient cold storage facilities to preserve hilsa fish for off season selling. Generally, in the market place of the investors, auctioneers sometimes store extra fish within cold stores.

\section{Ice manufacturer and supplier}

As is the case with cold storage, this item also constitutes a key function in preserving perishable items. However, requirements are more extensive and crucial than cold storage facilities. Supply of ice is equally required in both backward and forward phases of the supply chain to preserve perishable items adequately. During instances where the supply chain needs to cater for emergency levels of hilsa, this element of the supply chain is unable to accommodate demand leading to significant issues relating to preservation and quality.

\section{Government fisheries department}

Procurement, distribution, and all other supporting services of hilsa fish are controlled by free market mechanism and the government has little scope to regulate this market directly. However, as the policy maker, government authority such as the fisheries department has the responsibility and authority to oversee this market and intervene if necessary. The banning of catching fish during spawning periods is directly managed by this department.

\section{End consumers}

Customers buy hilsa from all regions within Bangladesh. Fish are generally bought from local retailers however, buying fish from local wholesaler is not uncommon. Demand for hilsa is extremely high and often supply exceeds demand. In instances where excessive supply enters the supply chain, the end customer is unlikely to benefit due to the numerous problems within the supply chain.

\section{Existing Supply Chain}

Interviews were gathered from major 10 locations of primary procurement and several floating locations of unauthorized or uncoordinated trading from different stakeholders (total 13 major stakeholders). Each stakeholder exhibited multidimensional interests and often conflicting objectives. The functions and interdependencies of the stakeholder groups were conceptualized from in-depth interviews of 345 members of the 13 major stakeholders. The existing supply chain of hilsa fish can be shown in Figure 2. 


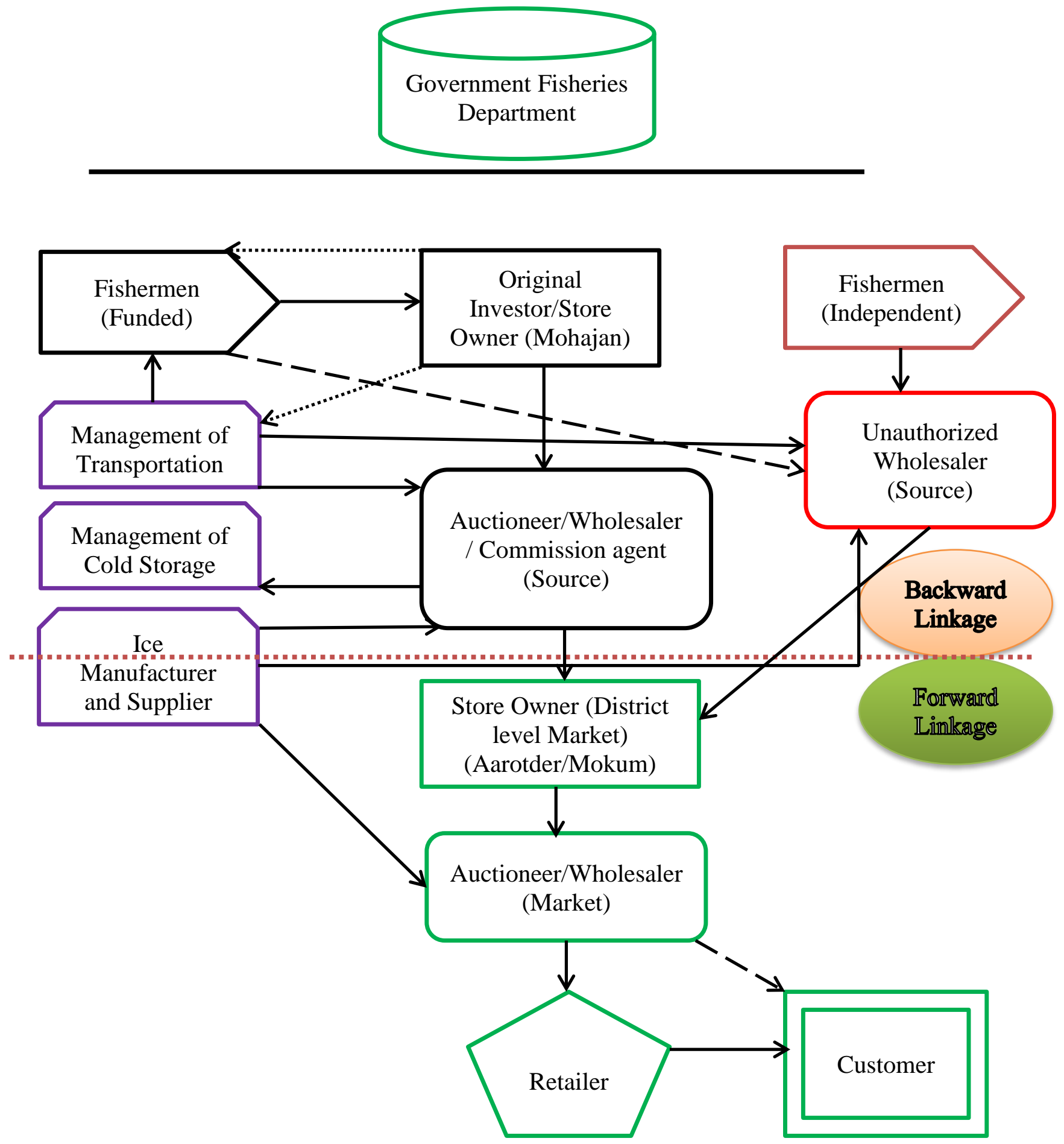

Figure 2: Existing supply chain of hilsa (Firm arrow: flow of fish; dotted arrow: flow of fund; dashed arrow: flow of limited levels of fish 


\section{Discussion}

The Thirteen major stakeholders associated with the hilsa supply chain have multidimensional and conflicting interests. Sustainability strategies are inadequate and the supply chain is ineffective particularly during emergency periods. The poor supply chain infrastructure restricts the timely distribution of product resulting in waste and lost revenues to many stakeholders. Distribution, logistics management and retail marketing are interlinked operations and require efficient integrated process with interoperable communication amongst all key stakeholders (Keith et al., 2003; Noor, 2012). The key to developing a sustainable strategy is to establish an improved strategy, structures and processes for the regular and emergency supply chain management of product (Ahmed, 2007; Islam, 2003; Noor, 2011). For hilsa, the inability of the supply chain to cope with emergency supply is a critical issue. Fishermen can frequently catch huge numbers of hilsa in a very short interval of time during the peak season, but the supply chain does not have the required infrastructure or flexibility to manage these instances.

Interviews were held with 345 participants representing the 13 key supply chain stakeholders. Their views can be summarized as follows:

- Supply of hilsa fish is inadequate to fulfil demand.

- Market infrastructure cannot store, distribute, transport, and retail product effectively.

- During emergency catch scenarios supplies of hilsa excessively surpass demand.

- Profits earned by fishermen are greatly impacted due to poor market infrastructure and logistics management.

- There is no emergency supply network for distributing excessive hilsa immediately and evenly throughout the country.

- Market development is inadequate to manage emergency supply chain.

- Chain of command among versatile groups is poor and disrupted.

- Logistics management and distribution network is inadequate and inefficient.

- Corruption exists within many elements of the supply chain.

- Lack of information sharing and government coordination.

- Infrastructure is poorly managed.

- Lack of coordination among members.

- Presence of illegal and unauthorized trading.

- Artificial shortage and illegal market control is frequent

\subsection{Identified supply chain issues}

The aforementioned supply chain problems can have contradictory and sometimes conflicting interests. As a result, the same problem identified from different stakeholders may have different significance. Members of recognized stakeholder groups reveal the problems from their own 
professional interests as well as from the perspective of overall supply chain of hilsa fish. Considering the significance, potential merits, and intended meaning, the identified issues are categorized into the following groups:

\section{Transportation management}

Studies have highlighted that stakeholders are unable to accurately estimate the required level of transportation for fish supply chains (Alam, 2011). Throughout the year, even during normal periods of supply and demand (August to January), estimates for required transportation range widely, thereby impacting logistic planning and control. During emergency instances where the transportation requirement ramps up in a short space of time, hilsa transportation is uncontrollable and unstable, directly impacting the longevity of perishable items. Transportation is required primarily at three phases in the supply chain: backward linkage for carrying fish from river bank (known as Ghat) or coaster area to the market place of the investors, forward linkage to distribute fish to different districts, and forward linkage to distribute fish from wholesalers to the retailer markets. During excess supply of fish, shortage of transportation is one issue. Increased supply chain cost is another important issue. For inter-district transportation, during emergency periods, transportation cost is extremely high thereby, restricting the benefits of adequate supply of fish to the end customer. This problem has been raised as a significant issue by the original investor/store owner, the auctioneer/wholesaler/ commission agent and transportation controllers.

\section{Future storage facility}

This term indicates the cold storage facility which can be used to store excess fish captured suddenly for future consumption. Since in the recent years, supply of fish is uncertain and hilsa is available almost throughout the year, investor, auctioneer or any district wholesalers do not find it feasible to store fish regularly in cold storage. As a result, availability of cold storage, particularly close to the market place of backward linkage (or procurement area) is insufficient. Specifically, cold storage capacity is inadequate during excess supply. The major stakeholders of procurement and distribution affirmed this issue.

\section{Present preservation: Supply of Ice}

Hilsa is an extremely perishable item and spoilage of hilsa begins as soon as the fish is caught (Ahmed et al., 1996; Alam et al., 2010; Al-Hasan et al., 2014; Rabby et al., 2015). A fundamental problem of hilsa fish procurement is poor handling, storage and prevention facilities (Ahmed et al., 1996). Timely and adequate ice packing is extremely important to preserve hilsa fish. As an ancillary product, for preservation, ice is an essential item. From procurement to distribution to final consumption, adequate ice packaging is essential in a number of phases:

- At the riverbank ghats or coastal ghats, just after the catch is landed by the funded fishermen

- At remote locations along the riverbank just after catch is landed by independent fishermen or during illegal trading

- When auctioneer/wholesaler/commission agent distributes fish through trucks to different districts.

- When local auctioneer/wholesaler stores the hilsa and sells on to retailers. 
Although sufficient ice is mandatory, this supply chain suffers shortage of ice during illegal trading at the aforementioned phase $b$ and in all phases during excess supply of fish, particularly at the last phase mentioned above.

\section{Available capital for fishermen to be equipped for fishing}

Scarcity of own capital for the fishermen is one of the fundamental issues for the uneven distribution of profit. Fishermen are deprived in their ability to establish and claim their rights in revenue distribution due to inability to fund their livelihoods. The fishermen do not have control over any aspects of financial management. Under the guidance of government, the fisheries cooperative was formed in 1960. This organization was reformed and renamed as the Bangladesh Jatio Matshyajibi Samabaya Samity (BJMSS) (Alam, 2011). The BJMSS intend to supply resources to fishermen at reasonable prices and issue loans to affiliated members (Alam, 2011). In reality, this support is almost negligible, and several fishermen have claimed that the capital support is not feasible without adequate financing arrangements directly from government. As it can be seen from Figure 1, existing supply chain network, the government has an umbrella effect on the entire management of procurement-to-consumption of hilsa fish. Stakeholders have certified that no catching or transportation of hilsa during high breeding period will be carried out. This guarantees the safe spawning of hilsa. Government does not try to intervene in this sustainability element of the supply chain (Hoque et al., 2017; Monir et al., 2013). During this period, government provides financial support to the fishermen at a sustenance daily expenditure level only.

The government fisheries authority in Bangladesh does not provide any financial support or provision of loans to procure fishing materials. As a result, poor fishermen have few options but to borrow funds to secure a boat and other necessary equipment. These funds come directly from investors (Mohajan). Fishermen must sell their entire catch to them. They have no control on pricing, trading, and preserving. After deduction of all expenditures and 6-8\% commission of investors as royalty, they are entitled to receive $50 \%$ profit at the end of the season. Many fishermen claimed that investors try to manipulate this figure (Dey et al., 2010; Hoque et al., 2017; Monir et al., 2013).

\section{Processing facility in market place}

This is another significant issue which severely hampers adequate preservation of fish and thus, distribution. Studies on hilsa fish distribution (Alam et al., 2010; Al-Hasan et al., 2014; Rabby et al., 2015) acknowledged that processing facilities within fish markets and informal procurement locations such as those adjacent to riverbanks (Ghat), are inadequate. Investors/store owners and auctioneer/wholesaler/commission agents complained that the assembly place for trading as well as riverbank is not organized and are unhealthy. Several participants stated that they visited many market places and riverbank ghats observing that assembly places are wet, dirty, muddy and dusty. Due to improper and unhygienic facilities, the quality of fish can deteriorate very quickly. This problem is more serious for many remote areas of Bangladesh where unauthorized wholesalers try to purchase fish from independent fishermen or provoke funded fishermen to sell their fish illegally. 


\section{Overall infrastructure}

This issue includes all infrastructure related facilities such as paved roads and trading places near to riverbanks and coastal areas, structured ghats, fish carrying routes from ghats to Mahajans' and covered areas functioning as assembly locations. Although the road infrastructure has been upgraded in recent times, many of the routes from remote ghats to market places are not well equipped, directly impacting lead times (Al-Hasan et al., 2014).

\section{Emergency preparedness for excessive supply}

Over the last couple of years, production of hilsa has increased meaning that more product is available throughout the year. However, supply quantity is still uncertain. In the main season, during monsoon, sometimes fishermen capture excessive supply. One of the fundamental problems inherent within the current supply chain, is the inability to cope with an emergency situation when fishermen land excessive hilsa but the market and trading system cannot handle the excess supply (Dey et al., 2010; Hoque et al., 2017; Monir et al., 2013). Many aspects of the supply chain fail to cope, impacting: market facilities, transportation systems (trucks, vans, and other human-haulers), procurement and distribution routes, ancillary supports such as supply of ice, packing materials, storage and preservation, processing areas and market places, human resources involved in the handling of product. All are not at all prepared for this kind of emergency period and significant levels of hilsa product are wasted.

\section{Involvement of many intermediaries and their control}

Researchers studying hilsa fish marketing in Bangladesh have identified a number of procurement and distribution problems. Studies have highlighted that the lack of sufficient controls has allowed intermediaries within the supply chain to effectively profit from other stakeholders without adding value (Alam, 2011; Hoque et al., 2017). These intermediaries are also responsible for raising prices and disadvantaging retail customers as well as fishermen (Dey et al., 2010; Monir et al., 2013). In the analysis of the existing supply chain of hilsa fish from Figure 1, there are currently five intermediaries involved in the movement of hilsa from procurement to the end customer. Price and profit is substantially controlled by investor, auctioneer, and district level wholesalers (Hoque et al., 2017). When auctions are conducted in several markets, price is significantly manipulated by the commission agents thereby, impacting all elements of the remaining supply chain. It is clear from reviewing the existing supply chain, that the hilsa processes can be easily streamlined with less intermediaries to expedite the system and ensure a more equitable profit distribution. It is recognised that established practice and related societal norms may impact change in this area, but a change toward a more streamlined supply chain could deliver positive benefits to all parties.

\section{Illegal or unauthorized trading}

This study visited ten established market places where fish are assembled after delivery from the catch locations. While visiting the established riverbank locations used for landing of fish from boat to land by funded fishermen, this study identified multiple temporary sites where illegal and unauthorized trading is conducted by independent as well as some funded fishermen. Some wholesalers purchase these fishes at a lower prices via cash purchase from any unauthorized places on the river or riverbanks. The problems of this practice are multidimensional impacting the consumers and existing supply chain (Halder, 2002; Kayalar, 2009). This practice accelerates illegal trading outside of the structured market place, quality of product and hygiene are affected, 
no adequate transportation and ice based packaging exists, resulting in spoilage of fish and below standard product.

\section{Government control}

One of the major issues within the supply chain of hilsa, is the lack of adequate government control. The Bangladeshi government has undertaken a number of initiatives to expedite hilsa production, with limited success (Sakib, 2012). However, government intervention has so far, failed to take steps to adequately monitor and control profit distribution among the stakeholders. Fishermen are beholden to the investors who in effect control major elements of the supply chain and hilsa selling prices. Studies have highlighted the benefits of a more equitable approach where the government could provide the required funding to the registered fishermen by developing a mechanism through their cooperative organization (Dey et al., 2010; Hoque et al., 2017; Monir et al., 2013; Sakib, 2012). Illegal trading can still be controlled and enforced by government. Participants interviewed suggested that government intervention could assist in the development of infrastructure, procurement and distribution routes, processing areas within markets, cold storage, and transport logistics. Generally, the participants felt that greater government control was required in the supervision of the entire supply chain of hilsa fish.

\section{Improper distribution from source by primary Auctioneer/Wholesaler/ Commission agent -} pull system driven by price not by demand

The primary auctioneer/wholesaler/commission agents are responsible for monitoring and control of the entire fish distribution from source of assembly point (Mohajan) to different Mokum districts. This "pull system" based distribution does not operate based on demand forecasts as in most market driven supply chains. The Bangladesh hilsa fish distribution is effectively driven by price data, where auctioneers distribute product to specific districts where the highest prices can be reached. Prices in these districts are influenced by social factors where purchasers are more affluent and greater profit margins can be gained by the agents. The net effect of these distribution biases is that hilsa product is not evenly distributed throughout Bangladesh. Within a true market economy, these practices can be seen as rational. However, in this instance the auctioneers with the help of district level wholesalers, effectively manipulate the market and deprive both consumers and fishermen. These practices can be only supervised via government intervention.

\section{Artificial shortage created by local wholesalers through storing excess amount without proper} storing facility (during emergency period when supply is excessive)

In this case, the market is manipulated at the district level where wholesalers directly suppress and control the supply of product. During sudden excess supply, local wholesalers, procure the entire distribution shipment from the source auctioneers and create artificial shortage removing product from the market to manipulate prices. This practice is undertaken throughout the distribution network but concentrates on specific markets where consumer purchasing capacity is higher, such as Dhaka, Chattagram and Sylhet. It was clear from the participant interviews that this practice created additional problems due to the shortage of resources to safely preserve the excess supplied fish as well as disenfranchising the Bangladeshi consumer from the benefits of a fair market price.

\section{Lack of interoperability, coordination and communication among relevant bodies.}

A number of market manipulation practices that are inherent within the existing supply chain, could be controlled to some extent, through greater control and coordination between the relevant 
bodies. The literature highlights the advantages of stakeholders sharing their views to benefit the common goal and interest of all parties in the network (Alam, 2011; Vanany et al., 2009; Xu \& Beamon, 2006). It was identified from the interviews that the major stakeholders do not formally coordinate or communicate. This is mainly due to the belief that their interests are viewed as competing, despite their presence in the same supply network. This is issue is complex and multidimensional reinforced by a lack of motivation to change practices due to self-interests. It is clear that overall communication and coordination is required throughout the supply network and that this should be managed by a government appointed body.

\section{Relatively unstable information management and poor forecasting capability}

Effective supply chains reply on systems that develop an efficient and up to date flow of accurate information for estimation and market forecasting (Alam et al., 2010; Rabby et al., 2015). From the participant interviews, it is clear that stakeholder self-interests develop a culture where it is the norm to hide true market demand and market supply. The net effect of this practice and lack of supporting systems and processes is the inability to support excess supply or manage a demand focussed distribution network. Greater government support in the establishment of required controls and systems could benefit the flow of information throughout the network.

\subsection{Problems Identified by Stakeholders and Relation with Existing Supply Chain Parameters}

The issues revealed by the various stakeholders associated with the existing supply chain occur at different stages of the network. Researchers have analysed Bangladeshi supply chain networks and have identified a number of multifaceted problems within the supply and distribution process. (Dey et al., 2010; Halder, 2002; Hoque et al., 2017; Monir et al., 2013; Sakib, 2012). These studies reveal a list of supply chain parameters that can be measured against the issues raised in this study. We evaluated these parameters against the 14 identified supply chain issues to further analyse the root causes of many of the current problems. Table 3 presents a matrix of the supply chain issues specific to hilsa vs the supply chain parameters from the existing literature. Reflecting the nature of the problems, the issues within the existing supply chain are interconnected with several areas of related supply chain parameters.

Table 3: Cross-matrix of the Problems of Existing Supply Chain of Hilsa Fish with Ten Areas of Supply Chain Parameters

\begin{tabular}{|c|c|c|c|c|c|c|c|c|c|c|}
\hline \multirow[b]{2}{*}{$\begin{array}{l}\text { Supply chain } \\
\text { issues }\end{array}$} & \multicolumn{10}{|c|}{ Supply Chain Parameters } \\
\hline & Planning & $\begin{array}{l}\text { Forecasting } \\
\& \quad \text { Supply } \\
\text { Uncertainty, }\end{array}$ & $\begin{array}{l}\text { Facility } \\
\text { Development }\end{array}$ & $\begin{array}{l}\text { Financing \& } \\
\text { Cost } \\
\text { Management }\end{array}$ & $\begin{array}{l}\text { Procurement } \\
\text { Site }\end{array}$ & $\begin{array}{l}\text { Storage and } \\
\text { Preservation }\end{array}$ & $\begin{array}{l}\text { Logistics } \\
\text { Management }\end{array}$ & $\begin{array}{l}\text { Distribution in } \\
\text { Emergency } \\
\text { Period }\end{array}$ & $\begin{array}{l}\text { Coordination \& } \\
\text { Communication }\end{array}$ & $\begin{array}{l}\text { Negotiation } \\
\& \\
\text { Supervisory } \\
\text { Control }\end{array}$ \\
\hline $\begin{array}{l}\text { Transportation } \\
\text { management }\end{array}$ & $\sqrt{ }$ & & & & & & $\sqrt{ }$ & & & \\
\hline $\begin{array}{l}\text { Future storage } \\
\text { facility }\end{array}$ & $\sqrt{ }$ & & & & & $\sqrt{ }$ & & & & \\
\hline
\end{tabular}




\begin{tabular}{|c|c|c|c|c|c|c|c|c|c|c|}
\hline $\begin{array}{l}\text { Present } \\
\text { preservation: } \\
\text { Supply of Ice }\end{array}$ & $\sqrt{ }$ & & & & & $\sqrt{ }$ & & & & \\
\hline $\begin{array}{l}\text { Available capital } \\
\text { for fishermen to } \\
\text { be equipped for } \\
\text { fishing }\end{array}$ & & & & $\sqrt{ }$ & & & & & & \\
\hline $\begin{array}{l}\text { Processing facility } \\
\text { in market place }\end{array}$ & & & $\sqrt{ }$ & $\sqrt{ }$ & & & & & & \\
\hline $\begin{array}{l}\text { Overall } \\
\text { infrastructure }\end{array}$ & & & $\sqrt{ }$ & & & & $\sqrt{ }$ & & & \\
\hline $\begin{array}{l}\text { Emergency } \\
\text { prepardess for } \\
\text { excessive supply }\end{array}$ & $\sqrt{ }$ & & $\sqrt{ }$ & & & $\sqrt{ }$ & $\sqrt{ }$ & $\sqrt{ }$ & & $\sqrt{ }$ \\
\hline $\begin{array}{l}\text { Involvement of } \\
\text { many } \\
\text { intermediaries and } \\
\text { their control }\end{array}$ & & $\sqrt{ }$ & & & $\sqrt{ }$ & & & $\sqrt{ }$ & & $\sqrt{ }$ \\
\hline $\begin{array}{l}\text { Illegal or } \\
\text { unuauthorized } \\
\text { trading }\end{array}$ & & $\sqrt{ }$ & & & $\sqrt{ }$ & & & & $\sqrt{ }$ & $\sqrt{ }$ \\
\hline $\begin{array}{l}\text { Government } \\
\text { control }\end{array}$ & & $\sqrt{ }$ & & & & & & & $\sqrt{ }$ & $\sqrt{ }$ \\
\hline $\begin{array}{l}\text { Improper } \\
\text { distribution from } \\
\text { source by primary } \\
\text { Auctioneer/Whole } \\
\text { saler//Commission } \\
\text { agent }\end{array}$ & & & & & & $\sqrt{ }$ & $\sqrt{ }$ & $\sqrt{ }$ & & $\sqrt{ }$ \\
\hline $\begin{array}{l}\text { Artificial shortage } \\
\text { created by local } \\
\text { wholesalers by } \\
\text { storing excess } \\
\text { amount without } \\
\text { proper storing } \\
\text { facility }\end{array}$ & & & & & & $\sqrt{ }$ & & $\sqrt{ }$ & & $\sqrt{ }$ \\
\hline $\begin{array}{l}\text { Lack of } \\
\text { interoperability in } \\
\text { coordination and } \\
\text { communication } \\
\text { among relevant } \\
\text { bodies }\end{array}$ & $\sqrt{ }$ & $\sqrt{ }$ & & & & & & & $\sqrt{ }$ & $\sqrt{ }$ \\
\hline $\begin{array}{l}\text { Relatively } \\
\text { unstable } \\
\text { information } \\
\text { management and } \\
\text { no forecasting } \\
\text { system for } \\
\text { estimation }\end{array}$ & $\sqrt{ }$ & $\sqrt{ }$ & & & & & $\sqrt{ }$ & $\sqrt{ }$ & $\sqrt{ }$ & \\
\hline
\end{tabular}

Based on the cross-matrix in Table 3, the following section illustrates and explains the identified problems in the light of interrelated parameters of supply chain parameters of hilsa fish.

\section{Planning}

Planning as an initial parameter needs to be focused on the interrelated problems of the supply chain. However, due to the inherent problems with the supply chain - developing a comprehensive plan is extremely difficult especially in instances where supply surpasses demand. Constructive and effective planning for integrated supply of hilsa is obstructed due to the problems created by 
stakeholder self-interests, inefficient transportation management, shortage of storage and preservation facilities, lack of emergency preparedness during excess supply, lack of interoperability in coordination and communication and relatively unstable information management.

\section{Forecasting \& Supply Uncertainty}

Procurement of hilsa is uncertain and data relating to accurate forecasting is not readily available. Although, August to October is typically considered to be the peak hilsa season and JanuaryFebruary is the second highest, significant levels of excess fish can be caught at any stage in the year (Sakib, 2012). Existing data relating to breeding patterns, change of life cycle and availability has failed to offer any predictive value of availability. Fishermen and local experts also fail to accurately forecast supply of hilsa within any specific time period. This lack of formal estimation based on basic data analytics of hilsa supply, is a major issue for the supply network. These issues are interrelated with many of the other logistics issues within the supply chain.

\section{Facility Development}

Appropriate facilities for procurement, processing, packaging and distribution are an essential parameter for supply chain management of any product (Hoque et al., 2017; Monir et al., 2013). For hilsa distribution, facility development includes development of many ghats close to the riverbanks in the rural areas, transportation routes to the investors market, processing zones for auction and packaging and distribution routes to other areas within Bangladesh. The existing supply chain suffers from poor facilities, inadequate processing areas within markets, poor infrastructure and lack of emergency preparedness.

\section{Financing \& Cost Management}

Since trading of hilsa is entirely governed by private sector, fishermen are financed by private investors (Mohajan) who function as traders. Prior to the season, fishermen use the investor money to purchase all the resources necessary including monthly food expenditure (Dey et al., 2010; Hoque et al., 2017; Monir et al., 2013). In exchange of this minimum investment, investors own the rights to control all aspects of the hilsa catch. Academic studies have highlighted the negative impact of this process, suggesting that the financing of fishermen, market processing zones, and riverbank assembly sites could be controlled by government authority (Halder, 2002; Kayalar, 2009, Sakib, 2012). Government control could effectively finance the registered fishermen through their cooperative society, effectively negating the need for the investor finance. This could radically change the control and dynamic of the initial stages of the supply chain where fishermen could regain more control of pricing and distribution.

\section{Procurement \& Site Selection}

For any perishable goods supply chain, site selection of for procurement and processing is extremely important to ensure quality standards and timely distribution (Alam, 2011; Kayalar, 2009). Within Bangladesh some remote procurement and processing sites are significantly below standard. This problem is exacerbated in instances of illegal trading, where hilsa is purchased close to riverbanks in poor quality conditions with minimal preservation. This situation is made worse by fishermen being tied to a market controlled by the investors and looking to make additional profit outside of the normal purchase and supply route. 


\section{Storage and Preservation}

The storage and preservation processes are an essential factor for the performance of perishable product supply chains (Kayalar, 2009; Vanany et al., 2009; Xu \& Beamon, 2006). One of the major issues within the existing supply chain is the efficient storage and preservation of hilsa fish. Cold storage and ice packaging facilities are adequate for the expected supply of hilsa, but do not have the inherent capacity or flexibility to cope with excessive supply. This lack of emergency preparedness leads to sub-standard distribution, unhygienic artificial shortage by local wholesalers and poor contribution to sustainability.

\section{Logistics Management}

For both the backward and forward linkages, logistics management plays a key role in effective management of supply chain (Vanany et al., 2009; Xu \& Beamon, 2006). If logistics management is not adequate, procurement, storage, preservation, and distribution suffer (Halder, 2002; Sakib, 2012). For hilsa distribution, logistics management is significantly underdeveloped and not equipped to provide support during emergency periods. These issues are compounded by the lack of available transport during excess market supply, underdeveloped infrastructure, improper distribution from source by primary auctioneers and unstable information management.

\section{Distribution in Emergency Period}

Distribution within emergency periods is an important component for the supply chain of perishable items (Alam, 2011; Stephenson, 2005). In the absence of government control investors, auctioneers and wholesalers are able to manipulate the market at the expense of the weaker stakeholders such as fishermen and retail customers. This issue is compounded by the interconnected problems relating to the lack of preparedness for emergency periods, involvement of too many intermediaries, improper distribution from source by primary auctioneers, creation of artificial shortage through manipulation of market supply and poor information management.

\section{Coordination \& Communication}

For complicated supply chains exhibiting conflicting and opposing interests, coordination and communication is imperative for success (Al-Hasan et al., 2014; Kayalar, 2009). However, due to self-serving interests and lack of oversight from authorities, some stakeholders within the hilsa supply chain effectively deprive other parties in the network and manipulate the market. A greater focus on the benefits of increased coordination and effective communication as part of a programme of improved processes, could deliver improvements to a number of stakeholders.

\section{Negotiation \& Supervisory Control}

This is not a common component of many commodity based supply chains. Studies have highlighted that within an effective market economy, supply chains should be managed by the spontaneous participation and empowerment of the acting stakeholders (Alam et al., 2010; Castañeda \& Gonçalves, 2018; Kayalar, 2009; Rabby et al., 2015). However, hilsa is not a true market commodity in that it is a natural resource. Additionally the bulk of fishermen can impose very little authority in the supply of hilsa (Hoque et al., 2017; Monir et al., 2013). Thus, the requirement of negotiation among the stakeholders and supervising role of government is potentially beneficial for the fishermen and end customers. 


\subsection{Study recommendations}

Focusing on the identified issues with the parameters of an effective supply chain for a perishable commodity, this study posits the following recommendations to improve the supply chain and logistics processes.

- Government should play a greater supervisory role within the supply chain. At present the government controls the banning of fishing for fixed periods to ensure sufficient production during the highest breeding period. Fishermen are currently financially supported for this period. However, this involvement is not sufficient to manage illegal trading and market manipulation.

- Illegal and unauthorized trading places close to river banks and coastal areas should be more closely policed. Close monitoring systems and frequent surveillance are essential in this regard.

- A formal state driven investment programme should be initiated to fund fishermen thereby, ensuring they are not forced to take loans from investors at high interest rates.

- Government should be involved in developing formal and hygienic processing zones near riverbanks, coastal areas and market places. Government also needs to facilitate developing cold storage facilities, supply of ice and cold storage distribution vehicles. Participant stakeholders have highlighted the potential benefits of utilising the cargo train network to carry fish to different districts. The train service can potentially offer a faster and cheaper service than the road alternative.

- Involvement of too many intermediaries impacts efficient distribution of product and deprives the stakeholders at the beginning and end of the supply chain. Some middlemen currently manipulate supply and therefore prices facilitated by the lack of monitoring within the network. Greater analysis from a value chain perspective to streamline the network could yield significant benefits for many stakeholders. This may require government intervention to ensure the vested interests are disrupted.

- Emergency preparedness is absent within the hilsa supply chain. Since the supply of hilsa is uncertain, an integrated policy for emergency periods should be developed to ensure all stakeholders within the supply chain can benefit.

- Supply chain stakeholders exhibit competing interests and motives. Consequently, coordination and communication is a problem in the management of an effective supply chain. Without interoperability among the conflicting stakeholders, establishment of an effective supply chain is not possible. It is recommended that the government fisheries department should take a supervisory role to ensure effective movement of product throughout the network.

- At present, stakeholders are not incentivised to share information. Some traders have a vested interest in hiding or suppressing information from other stakeholders to manipulate the supply network. If profit sharing cannot be regulated through a more equitable 
distribution of key data, market regulation should enforce these aspects with tighter controls or new systems.

\subsection{Theoretical and Managerial Implications}

This study focuses on an existing inefficient supply chain that is critical to the Bangladeshi people. The hilsa fish supply chain has several unique characteristics, many of which are historical and cultural in context. Complexities arise due to competing stakeholder interest, inefficient supply chain, poor communication systems and inadequate logistics management. The existing literature has analysed the Bangladesh fisheries industry from the sustainability perspective (Halder, 2002; Hoque et al., 2017), but has omitted to offer a rigorous academic analysis of the supply chain and distribution problems specific to hilsa production. This research uses a case study approach to offer academic insight and contribution to theory by delivering new perspectives on the problems relating to the hilsa supply chain. The recommendations within this study offer additional contribution by highlighting the potential benefits to key stakeholders that are currently disadvantaged by established processes. This study highlights the problems within a multidimensional supply chain and the fact that the free market at times is unable or not motivated to deliver efficiencies in the sustainability context. Our recommendation that government should intervene in this market to supervise the entire supply chain is an important point for academics and researchers in this field. This point is a recognition that direct intervention by an authority can effect change where existing free markets are unable to self-organise to solve inherent problems.

This study contributes to the practitioner perspective in instances where they could be dealing with the supply chain of perishable items. Managers can potentially gain insight from the many problems of the hilsa supply chain and the impact of conflicting priorities on the efficient operation of the supply chain. These are important observations that can inform practice and can be directly transferrable to other emerging markets in a number of cultural contexts. These findings are also transferrable to other supply chain areas related to perishable food items within emerging markets. Food security is a significant issue for contemporary supply chain management and this study can offer contribution to the existing literature in this field.

\subsection{Limitations and Future Research Direction}

This study has focused on a specific perishable product and the many issues within the existing supply chain in Bangladesh. Future research could explore related supply chains that are impacted due to similar factors and inherent issues that could be improved from greater academic analysis. This study did not study the nature and extend of government market control. As a result any recommendation for government involvement is not specific and it could be further analysed within future research. This study investigated the supply chain issues relating to emergency scenarios but could not collect this data during an actual emergency period. Future researchers could potentially seek to add additional contribution by collecting data from the key stakeholders when the hilsa supply is excessive. 


\section{Conclusions}

This study analysed the numerous problems within the existing supply chain of hilsa - the national fish of Bangladesh. Hilsa significantly contributes to national GDP and several million people are involved in the supply chain of this national resource. The study utilised participants from a number of key stages within the existing supply chain including hilsa procurement and distribution. The researchers visited ten significant locations used for hilsa processing and a number of unauthorized trading locations close to the riverbanks and coastal areas. Several wholesale and retail markets in a number of districts in Bangladesh were also visited. Interviews were conducted via a semi-structured method with 345 members of the supply chain. The qualitative answers were broken down to measurable keywords, categorized and grouped to reveal the significances. Based on those opinions, 14 generic problems depicting weaknesses of the existing supply chain were identified. The study developed a matrix where the existing supply chain problems were analysed against parameters based on supply chain management issues from the literature.

The results highlight the inherent complexities of established practices and how elements of the supply chain are self-serving in their attempts at manipulating the market. There are currently few incentives for key stakeholders to cooperate and share information to develop a more efficient and effective supply chain. The existing supply chain problems are exacerbated in instances where excessive hilsa are caught by fishermen and the additional product is fed into the supply chain. The lack of controls and oversight by government allow the numerous intermediaries and market owners to manipulate supply by temporarily storing excess hilsa, thereby supporting existing price levels. Studies have posited the benefits of increased levels of information sharing and communication throughout the supply chain network to mitigate a number of these issues. This research supports many of the findings within the literature and recommends greater government involvement in the provision of investment finance for fishermen to liberate them from the closed market of the tied investor network. We also recommend additional government oversight and controls to deliver greater sustainability throughout the supply chain and improved shared equity for the key hilsa stakeholders.

\section{References}

ACDI-VOCA. (2006). World Report Fall (2006). The Value Chain Approach; Strengthening Value Chains to Promote Economic Opportunities, ACDI-VOCA, Accessed 12th August 2010, http://www.acdivoca.org/site/ID/resources_worldreportfall06.

Ahmed, K., Kamal, M., Haque, M. E., Chakraborty, S. C., Islam, M. N., \& Uddin, M. N. (1996), Postmortem changes in hilsa fish-II. Studies on physical and bacteriological changes in iced and frozen stored hilsa fish (Tenua/osa ilisha Ham.), Bangladesh Journal of. Fish Research, 1(1), 101-110. 
Ahmed, N. (2007). Value chain analysis for Hilsa marketing in coastal Bangladesh, Aquaculture News, University of Sterling, Sterling, UK, January 2007, pp 14-19.

Ahmed, N., Rahman M.M., \& Rahman, M.M. (2008). A Study on Fish Marketing Systems in Gazipur, Pakistan Journal of Biological Sciences, 8(2): 287-292.

Al-Hasan, A., Shahjahan, M., Hossain, M. M. \& Haque, M. M. (2014), Fish Availability and Marketing System at Three Markets in Barisal, Bangladesh, International Journal of Innovation and Applied Studies, 7(2), 765-773.

Alam, F., Palash, S., Mian, I.A. \& Day, M.M. (2012). Marketing of major fish species in Bangladesh: a value chain analysis. Rome, FAO.

Alam, M J, Yasmin R, Rahman A, Nahar N, Pinky N I and Hasan M. (2010). A study on fish marketing system in swarighat, Dhaka, Bangladesh. Nat. Sci. 8 (12):96-103.

Alam, M. F. (2011), A Background Paper for Bangladesh Fisheries Value Chain Study, Presented in Institute of Agricultural and Food Policy Studies, Universiti Putra Malaysia,1-25.

Alam, M.S. (2012). Hilsa fisheries management in Bangladesh: A paradigm in natural resources conservation. In: Anon (ed.) Hilsa: Status of fishery and potential for aquaculture, proceedings of the regional workshop held in Dhaka, 16-17 September 2012. Dhaka, The WorldFish Bangladesh and South Asia Office. pp. 224-238.

Ali, I., Nagalingam, S., \& Gurd, B., (2017) Building resilience in SMEs of perishable product supply chains: enablers, barriers and risks, Production Planning \& Control, 28:15, 1236-1250.

Ardjosoediro I. \& Goetz F. (2007). A value chain assessment of the aquaculture sector in Indonesia, U.S. Agency for International Development, USA.

Balcik, B., Beamon, B.M., Krejci, C.C., Muramatsu, K.M., Ramirez, M. (2010). "Coordination in humanitarian relief chains: Practices, challenges and opportunities", International Journal of Production Economics, 126 (1), 22-34.

Barratt, M., Choi, T. Y., \& Li, M. (2011). Qualitative case studies in operations management: Trends, research outcomes, and future research implications. Journal of Operations Management, 29(4), 329-342.

Bhuiyan, S. S., Joadder, M. A. R., \& Bhuiyan, A. S. (2008). Occurrence of fishes and non-fin fishes of the River Padma near Rajshahi, Bangladesh. University Journal of Zoology, Rajshahi University, 27, 99-100. 
BOLME, (2011). Report of the Bangladesh Hilsa Working Group Meeting, 19 May, 2011, Dhaka, Bangladesh, BOLME-2011, Ecology-12.

Castañeda, J. A., and P. Gonçalves. 2018. "Ordering Behavior in a Newsstand Experiment." International Journal of Production Economics 197: 186-196.

Childe,S.J. (2011).Case studies in operations management. Production Planning \& Control, 22(2), 107, DOI: 10.1080/09537287.2011.554736.

Cozzolino Alessandra., "Humanitarian Logistics: Cross-sector Cooperation in Disaster Relief Management", Chapter-2, Page-13, Springer, 2012.

Davis, L. B., F. Samanlioglu, X. Qu, and S. Root. 2013. "Inventory Planning and Coordination in Disaster Relief Efforts.” International Journal of Production Economics 141 (2): 561-573.

de Camargo Fiorini, P., \& Jabbour, C. J. C. (2017). Information systems and sustainable supply chain management towards a more sustainable society: Where we are and where we are going. International Journal of Information Management, 37(4), 241-249.

De Silva, D.A M. (2010). Value chain of fish and fishery products: origin, functions and application in 377 developed and developing country markets, Value chain project, Food and Agriculture Organisation 378 (FAO), Rome Italy. pp 7-10.

Dey, M. M., M.F. Alam, and M. L.Bose. 2010. Demand for aquaculture development: perspectives from Bangladesh for improved planning. Reviews in Aquaculture 2: 1-17.

Diallo, C., Venkatadri, U., Khatab, A., \& Bhakthavatchalam, S. (2017). State of the art review of quality, reliability and maintenance issues in closed-loop supply chains with remanufacturing, International Journal of Production Research, 55(5), 1277-1296.

Dreyer, H. C.,Strandhagen, J. O., Hvolby, H-H., Romsdal, A., \& Alfnes, E., (2016) Supply chain strategies for speciality foods: a Norwegian case study, Production Planning \& Control, 27:11, 878-893.

Dubey, R., Altay, N., Gunasekaran, A., Blome, C., Papadopoulos, T., \& Childe, S. J. (2018), Supply Chain Agility, Adaptability and Alignment: Empirical Evidence From the Indian Auto Components Industry. International Journal of Operations \& Production Management (accepted). Dubey, R., Gunasekaran, A., \& Ali, S.S. (2015). Exploring the relationship between leadership, operational practices, institutional pressures and environmental performance: A framework for green supply chain. International Journal of Production Economics, 160(February), 120-132. 
Dubey, R., Gunasekaran, A., Childe, S. J., Papadopoulos, T., Hazen, B., Giannakis, M., \& Roubaud, D. (2017). Examining the effect of external pressures and organizational culture on shaping performance measurement systems (PMS) for sustainability benchmarking: Some empirical findings. International Journal of Production Economics, 193, 63-76.

Dubey, R., Gunasekaran, A., Papadopoulos, T., Childe, S., Shibin, K., Wamba, S., (2017a). Sustainable supply chain management: framework and further research directions. Journal of Cleaner Production, 142 (Part 2), 1119-1130.

Dwivedi, Y.K., Shareef, M.A., Mukerji, B., Rana, N.P. \& Kapoor, K.K. (2018), Involvement In Emergency Supply Chain For Disaster Management: A Cognitive Dissonance Perspective, International Journal of Production Research, 56(21), 6758-6773.

Eisenhardt, K. M. (1989). Building theories from case study research. Academy of Management Review, 14(4), 532-550.

Fahimnia, B., J. Sarkis, and H. Davarzani. 2015. “Green Supply Chain Management: A Review and Bibliometric Analysis.” International Journal of Production Economics 162: 101-114.

Fernández Campos, P., Trucco, P., \& Huaccho Huatuco, L. (2019). Managing structural and dynamic complexity in supply chains: insights from four case studies. Production Planning \& Control, 113.

Garcia-Garcia, G., Woolley, E., Rahimifard, S., 2015. A framework for a more efficient approach to food waste management. Int. J. Food Eng, 1 (1), 65e72.

Gopal, P. R. C., and J. Thakkar. 2016a. "Sustainable Supply Chain Practices: An Empirical Investigation on Indian Automobile Industry.” Production Planning and Control 27 (1): 49-64.

Gopal, P. R. C., and J. Thakkar. 2016b. “Analysing Critical Success Factors to Implement Sustainable Supply Chain Practices in Indian Automobile Industry: A Case Study." Production Planning and Control 27 (12): 1005-1018.

Grimm, J. H., J. S. Hofstetter, and J. Sarkis. 2014. "Critical Factors for Sub-supplier Management: A Sustainable Food Supply Chains Perspective." International Journal of Production Economics, 152, 159-173.

Halder, G. C. 2002. Hilsa fishery management action plan for Bangladesh. Completion report of the studies conducted under the ARDMCS, GEF component; and FFP. Report No. 38.9, Department of Fisheries, Dhaka, Bangladesh. 
Haque, M.E. (2011). Fisheries News Analysis: New Threats on Hilsa Fishery of Bangladesh, BdFISH.

Hasegan, M., Nudurupati, S., \& Childe, S. J., (2018), Predicting Performance - A Dynamic Capability View, International Journal of Operations \& Production Management (Accepted), DOI: 10.1108/IJOPM-10-2016-0601.

Hasin, M. A. A., Thuy, N. T., \& Shareef, M. A. (2000). Implications of Selected Production Planning Functions: Impact Analysis through Simulation. Production Planning \& Control, 11(7), 641-647.

Heaslip, G., A. M. Sharif, and A. Althonayan. 2012. "Employing a Systems-Based Perspective to the Identification of Inter-Relationships within Humanitarian Logistics.” International Journal of Production Economics, 139 (2): 377-392.

Hoque, F., Akter, A., Chakraborty, J., Dewan, B. \& Khatun, M. (2017), Hilsha Fish Marketing Strategies in Dhaka city of Bangladesh, Journal of Research in Business, Economics and Management, 9(4), 1741-1749.

Hung, K.-T., and Ryu, S., (2008), “Changing Risk Preferences in Supply Chain Inventory Decisions.” Production Planning \& Control, 19 (8): 770-780.

Hussain, M.G. \& Hoq, M.E. (eds.), (2010). Sustainable management of fisheries resources of the Bay of Bengal-Complication of different workshop reports. Support to Sustainable Development of BOBLME Project, Bangladesh Fisheries Research Institute, SBOBLMEP Pub./Rep.2.122p.

Hussain, M.M. \& Uddin, M.H. (1995). Quality Control and Marketing of Fish and Fish Products: Needs for Infrastructure and Legal Support. 9, 233-272.

Irani Z, Sharif A.M, Lee H, Aktaş E, Topaloğlu Z, van’t Wout T and Huda S. (2018). Managing food security through food waste and loss: Small data to big data, Computers and Operations Research, 98(10): 367-383.

Irani, Z., Gunasekaran, A., \& Dwivedi, Y. K. (2010). Radio frequency identification (RFID): research trends and framework. International Journal of Production Research, 48(9), 2485-2511.

Islam, M.M., Mohammed, E.Y. \& Ali, L. (2016). Economic incentives for sustainable hilsa fishing in Bangladesh: An analysis of the legal and institutional framework, Marine Policy, 68, 8-22.

Islam, M.S. (2003). Perspectives of the coastal and marine fisheries of the Bay of Bengal, Bangladesh. Ocean \& Coastal Management, 46(8), 763-796. 
Jabbour, C. J. C., \& de Sousa Jabbour, A. B. L. (2016). Green human resource management and green supply chain management: Linking two emerging agendas. Journal of Cleaner Production, 112, 1824-1833.

Jabbour, C. J.C., Mauricio, A. L., \& Jabbour, A. B. L. D. S. (2017). Critical success factors and green supply chain management proactivity: shedding light on the human aspects of this relationship based on cases from the Brazilian industry. Production Planning \& Control, 28(6-8), 671-683.

Kannan, D., de Sousa Jabbour, A. B. L., \& Jabbour, C. J. C. (2014). Selecting green suppliers based on GSCM practices: Using fuzzy TOPSIS applied to a Brazilian electronics company. European Journal of Operational Research, 233(2), 432-447.

Kayalar, J. (2009), MIA Philippines, Richard Ivey School of Business, Ivey Management Services, $1-20$.

Keith, U., Alam, K., Dastidar, R., Datta, U., Oudwater, N., \& Ward, A. (2003). Livelihoods in Coastal Fishing Communities and the Marine Fish marketing Systems of Bangladeh. NRI Report No. 2712, Natural Resources Institute (NR), Greenwich University, London.

Ketokivi, M., \& Choi, T. (2014). Renaissance of case research as a scientific method. Journal of Operations Management, 32(5), 232-240.

Kiil, K. Dreyer, H. C. Hvolby, H-H., \& Chabada, L. (2018) Sustainable food supply chains: the impact of automatic replenishment in grocery stores, Production Planning \& Control, 29(2), 106116.

Kshetri, N. (2018). 1 Blockchain's roles in meeting key supply chain management objectives. International Journal of Information Management, 39, 80-89.

Kummu, M.; de Moel, H.; Porkka, M.; Siebert, S.; Varis, O.; Ward, P.J. (2012), Lost food, wasted resources: Global food supply chain losses and their impacts on freshwater, cropland, and fertilizer use. Science of Total Environment, 438, 477-489.

Lang, T., \& Barling, D. (2012). Food security and food sustainability: reformulating the debate. The Geographical Journal, 178(4), 313-326.

Marshall, D., L. McCarthy, C. Heavey, and P. McGrath. 2015. "Environmental and Social Supply Chain Management Sustainability Practices: Construct Development and Measurement." Production Planning and Control, 26 (8): 673-690.

Meredith, J. (1998). Building operations management theory through case and field research. Journal of Operations Management, 16(4), 441-454. 
Midgley, J.L., 2013. The logics of surplus food redistribution. Journal of Environmental Planning and Management, 57 (12), 1872-1892.

Moazzam, M., Akhtar, P., Garnevska, E., \& Marr, N. E., (2018) Measuring agri-food supply chain performance and risk through a new analytical framework: a case study of New Zealand dairy, Production Planning \& Control, 29:15, 1258-1274.

Monir, M . S., Haque, M . R. \& Rahman, S. (2013). Dry Fish Marketing in Nilphamari District of Bangladesh, Journal of Science and Technology, 11: 32-36.

Moon, M. D. (2019), Triangulation: A Method to Increase Validity, Reliability, and Legitimation in Clinical Research, Journal of Emergency Nursing, 45(1), 103-105.

Noor, S.M.A. (2011). Fish carrying transporters in different fish markets of Rajshahi City Corporation, BdFISH.

Noor, S.M.A. (2012). Marketign channel of some major fish groups in fish markets of Rajshahi City Corporation area, BdFISH.

Ou, C. S., Liu, F. C., Hung, Y. C., \& Yen, D. C. (2010). A structural model of supply chain management on firm performance. International Journal of Operations \& Production Management, 30(5), 526-545.

Pagell, M., \& Wu, Z. (2009). Building a more complete theory of sustainable supply chain management using case studies of 10 exemplars. Journal of supply chain management, 45(2), 3756.

Prater, E., Biehl, M., \& Smith, M. A. (2001). International supply chain agility-Tradeoffs between flexibility and uncertainty. International Journal of Operations \& Production Management, 21(5/6), 823-839.

Queiroz, M. M., \& Wamba, S. F. (2019). Blockchain adoption challenges in supply chain: An empirical investigation of the main drivers in India and the USA. International Journal of Information Management, 46, 70-82.

Rabby, A. F., Hossain, M. A., Alam, M. T., Uddin, M. S., \& Dey, T. (2015), Status and economics of three Upazilla fish markets in Moulavibazar district in Bangladesh, Journal of Sylhet Agricultural. University, 2(1):87-95.

Rahman, M., Khatun, S., Hossain, M.B., et al. (2013). Present scenario of landing and distribution of fish in Bangladesh. Pakistan Journal of Biological Sciences. 16, 1488-1495. 
Rahman, M.A., Alam, M.A., Hasan, S.J. \& Zaher, M. (2012). Hilsa (Tenualosa ilisha) fishery management in Bangladesh. In: Anon (ed.) Hilsa: Status of fishery and potential for aquaculture, proceedings of the regional workshop held in Dhaka, 16-17 September, 2012, Dhaka, The World Fish Bangladesh and South Asia Office. pp. 40-60.

Ransikarbum, K., \& S. J. Mason. 2016a. “Goal Programming-Based Post-Disaster Decision Making for Integrated Relief Distribution and Early-Stage Network Restoration.” International Journal of Production Economics, 182: 324-341.

Ransikarbum, K., and S. J. Mason. 2016b. "Multiple-Objective Analysis of Integrated Relief Supply and Network Restoration in Humanitarian Logistics Operations." International Journal of Production Research, 54 (1): 49-68.

Sakib, M. H. (2012), Status of hilsa (tenualosa ilisha) fishery in Bangladesh, Paper presented at graduate seminar course, Dept. of AER, BSMRAU,Gazipur, 1-35.

Salini, J. P., Milton, D. A., Rahman, M. J., \& Hussain, M. G. (2004). Allozyme and morphological variation throughout the geographic range of the tropical shad, hilsa Tenualosa ilisha, Fisheries Research, 66, 53-69.

Seles, B. M. R. P., de Sousa Jabbour, A. B. L., Jabbour, C. J. C., \& Dangelico, R. M. (2016). The green bullwhip effect, the diffusion of green supply chain practices, and institutional pressures: Evidence from the automotive sector. International Journal of Production Economics, 182, 342355.

Shareef, M. A., Dwivedi, Y. K., \& Kumar, V. (2016), Mobile Marketing Channel: Mobile Phone SMS \& Online Consumer Behavior, Springer, USA.

Shareef, M. A., Dwivedi, Y. K., Mahmud, R., Wright, A., Rahman, M. M., Kizgin, H., \& Rana, N. P. Disaster Management in Bangladesh: Developing an Effective Emergency Supply Chain Network, Annals of Operations Research, (In Press).

Shiau, W. L., Dwivedi, Y. K., \& Tsai, C. H. (2015). Supply chain management: exploring the intellectual structure. Scientometrics, 105(1), 215-230.

Shibin, K. T., Dubey, R., Gunasekaran, A., Luo, Z., Papadopoulos, T., \& Roubaud, D. (2018). Frugal innovation for supply chain sustainability in SMEs: multi-method research design. Production Planning \& Control, 29(11), 908-927.

Stephenson, M. (2005). "Making humanitarian relief networks more effective: operational coordination, trust and sense making”. Disasters, 29 (4) 337-350. 
Stevenson, M., \& Spring, M. (2009). Supply chain flexibility: an inter-firm empirical study. International Journal of Operations \& Production Management, 29(9), 946-971.

Su, Q., J. H. Shi, and S. J. Lai. 2008. "Study on Supply Chain Management of Chinese Firms from the Institutional View." International Journal of Production Economics 115 (2): 362-373.

Surana, A., Kumara, S., Greaves, M., Raghavan, U.N. (2005). "Supply chain networks: a complex adaptive systems perspective”. International Journal of Production Research, 43 (15), 4235-4265.

Vanany, I., Zailani, S., \& Pujawan, N. (2009). "Supply chain risk management: Literature review and future research". International Journal of Information Systems and Supply Chain Management, 2(1), 16-33.

Vlajic, J. V., van Lokven, S.W.M., Haijema, R. \&. van der Vorst, J.G.A.J. (2013) Using vulnerability performance indicators to attain food supply chain robustness, Production Planning \& Control, 24:8-9, 785-799.

Wu, J., X. Zhai, C. Zhang, and X. Liu. (2011). Sharing Quality Information in a Dual-supplier Network: A Game Theoretic Perspective, International Journal of Production Research, 49 (1), $199-214$.

Wu, L., \& Chiu, M. L. (2018). Examining supply chain collaboration with determinants and performance impact: Social capital, justice, and technology use perspectives. International Journal of Information Management, 39, 5-19.

$\mathrm{Xu}$, L., \& Beamon, B.M., (2006). "Supply chain coordination and cooperation mechanisms", The Journal of Supply Chain Management, Winter, 4-12.

Zheng, B., Yang, C., Yang, J., \& Zhang, M. (2017). Dual-channel closed loop supply chains: Forward channel competition, power structures and coordination. International Journal of Production Research, 1-18.

Zhu, Q., J. Sarkis, and K. H. Lai. 2012. "Examining the Effects of Green Supply Chain Management Practices and Their Mediations on Performance Improvements." International Journal of Production Research, 50 (5): 1377-1394. 


\section{Appendix A}

1) What are the major problems you face in the existing cycle of procurement-2-final consumption of hilsa fish related to appropriate sharing and distribution of profit for all major stakeholders.

2) What are the major problems you face in the existing cycle of procurement-2-final consumption of hilsa fish related to logistics management for distribution of hilsa fish to the end customers.

3) What are the major problems you face in the existing cycle of procurement-2-final consumption of hilsa fish related to quality of preservation of hilsa fish at different levels.

4) What are the major weaknesses in the entire cycle of procurement-2-final consumption of hilsa fish you face from your professional interest.

5) What are the major issues you need to change/modify in the entire cycle of procurement-2-final consumption of hilsa fish to improve your professional profit.

6) What are the major issues you need to change/modify in the entire cycle of procurement-2-final consumption of hilsa fish to ensure optimum profit sharing among all the major stakeholders.

7) What are the major issues you need to change/modify in the entire cycle of procurement-2-final consumption to ensure efficient logistics management for distribution of hilsa fish to the end customers.

8) What are the major issues you need to change/modify in the entire cycle of procurement-2-final consumption to ensure quality of preservation of hilsa fish at different levels

9) What are your primary suggestions to develop an effective supply chain which can help to develop a good profit sharing business model for hilsa project considering the entire cycle of procurement2-final consumption maintain quality of fish.

10) What your primary expectations based on your professional interest from the related government authorities. 